\title{
NATIONAL HEROES IN THE INDONESIAN REVOLUTION AND THE MEANING FOR YOUNG GENERATION
}

\author{
By \\ Ida Bagus Brata ${ }^{1}$, Ida Bagus Rai ${ }^{2}$, Ida Bagus Seloka ${ }^{3}$ \\ ${ }^{1,3}$ Faculty of Teacher Training and Education, Universitas Mahasaraswati Denpasar \\ ${ }^{2}$ Faculty of Teacher Training and Education, Universitas Dwijendra \\ Email: ${ }^{1}$ ibbrata@ unmas.ac.id, ${ }^{2}$ ib.rai.undwi@gmail.com, ${ }^{3}$ selokaidabagus574@unmas.ac.id
}

\begin{tabular}{l}
\hline Article Info \\
\hline Article History: \\
Received:13-10-21 \\
Revised : 16-11-21 \\
Accepted: $24-11-2021$
\end{tabular}

Keywords:

Heroes, Revolution,

Young Generation

\begin{abstract}
Awareness of Indonesian nationalism reached its peak after independence. The heroic values inherited by historical actors must be imitated by the next generation of this nation. This paper explored the national heroes in the Indonesian revolution and their meaning for the younger generation. The method used in reviewing the problem is a literature study by studying various sources such as books, published scientific articles that are relevant to the research study. The results of the study showed that in the context of inheritance, a comprehensive understanding of the values of heroism is needed so that the meaning and spirit of Indonesian nationalism continued to prioritize the ideals of the nation so that it could exist more in the midst of a highly competitive global era. Today's life is coloured by various competitions in line with the universal process marked by the loosening of national boundaries so that the challenges faced by a nation are increasingly complex. The younger generation of the nation's successors is required to appear in front of taking a role in global competition. However, in order not to lose direction and even identity, the figure of a hero in wartime who was so instrumental in politics and diplomacy, and in the post-independence period needs to be followed by the younger generation in fulfilling independence and continuing their ideals of struggle.
\end{abstract}

This is an open access article under the CC BY-SA license.

\section{Corresponding Author:}

Ida Bagus Brata,

Faculty of Teacher Training and Education,

Universitas Mahasaraswati Denpasar,

Email: ibbrata@unmas.ac.id

\section{INTRODUCTION}

Heroes' Day is the best momentum for Indonesia to commemorate the service and the spirit of heroes who fought for the sake of realizing the ideals of the independence of their homeland. The spirit of heroism that has been embodied by the heroes is a charity of struggle that is dedicated to the nation and its homeland [1]. The young generation must know how the struggles of the heroes in the past must be remembered, imitated, and used as lessons so that their values can be used as references to build Indonesian society so that they become a more dignified nation.

In the life of a nation, the young generation has an important role in the progress of civilization, therefore the younger generation of the nation's successor must have knowledge of the dynamics of national life [2]. The younger generation is those who consist of people who are individual and social beings must realize that every decision taken is not only related to themselves but also has implications in social life and even the environment in which they live. The heroic values inherited by the heroes are moral guidelines that can be actualized into concrete actions that involve various aspects of life around their lives. Therefore, the exemplary values of heroes need to be further actualized at every step-in decision making, so that they are able to reflect a pious and polite personality based on morals.

The heroes are actually superior humans mentally, physically, and spiritually healthy, demonstrated by high morality and good because they are clean (holy) born from a selective process, accepted by the environment, forged, educated, and trained so that they are able to carry out their duties. The duties of religion and state in a professional and proportional [3]. This certainly became an inspiration when the fighters succeeded in seizing and re-establishing 
the independence that had been proclaimed on August 17, 1945 [4]. It is for the sacrifices that have been made, as a form of respect for the services of the heroes, Heroes' Day was established.

National Hero is a title given to Indonesian citizens who fought against colonialism who died in defense of the Indonesian nation and state [5]. The stipulation of 10 November as Heroes' Day is based on Presidential Decree No. 316 of 1959 concerning National Days that are not Holidays. In the Presidential Decree, there are six historic days that are designated as national days instead of holidays, namely: National Education Day on May 8, National Awakening Day on May 20, Armed Forces Day on October 5, Youth Pledge Day on October 28, Hero Day on 10 November, and Mother's Day on December 22. November 10 is a phenomenal Heroes' Day and at the same time as evidence of the great history of the Indonesian nation which to this day remains embedded in the hearts of the Indonesian people. Every November 10, the Indonesian people always commemorate Heroes' Day.

Heroes' Day is celebrated by schoolchildren to office employees, without exception. National important days such as Heroes' Day were introduced through the earliest schooling education, namely Kindergarten. At this level, students are introduced to national holidays, names of national figures through ceremonies. At elementary schools, students are introduced to historical events that occur around them. At the junior high school level, the relationship between one event and another is introduced. Meanwhile, at the high school level, an understanding of the struggle to build national life was introduced by historical actors through their thoughts, words, and actions.

This paper explored the national heroes in the Indonesian revolution and their meaning for the younger generation. They received an award from the Government of the Republic of Indonesia as national heroes for their services and loyalty to the Republic of Indonesia. This loyalty and sincerity in sacrificing his body and soul is what must be understood and imitated by the younger generation who will succeed in the nation's struggle. The question that arises is whether the important days that are set from historical events are only important to be made as ceremonial days. Is it important because it is enlivened by various competitions or is it because those who will take part in the ceremony must dress nicely and formally, and after the ceremony is finished they then return to the routine of daily life without any meaning.

It must be admitted that even though this nation every year in November commemorates Heroes' Day, in reality, there are still many people who do not know why November 10 is celebrated as Heroes' Day. Heroes' Day is a day when the Indonesian nation remembers the services of heroes who have been willing to sacrifice their souls and bodies, spilled their blood to fight the invaders for the independence of their nation [6]. The heroes fought on the battlefield at the cost of their lives to defend the independence of their homeland. In this paper, as a discussion material, we will try to show the figures of war heroes and diplomatic heroes from Bali.

\section{RESEARCH METHOD}

The research method used in examining this research problem was a literature study by studying various sources such as books, published scientific articles that are relevant to the research study [7]. In this way, various problems related to the problems that were studied in this paper are discussed argumentatively and analyzed critically. Through conducting these steps, it was hoped that data and information obtained about the problem were sufficiently collected for the purpose of this study. After the data were collected, the data were triangulated to establish valid and reliable data. Through the triangulation process, the facts obtained in this study have high credibility and could be accounted for. The facts were then assembled completed with interpretation meaning so that they became meaningful historical works.

\section{RESULTS AND ANALYSIS}

\section{Heroes, Heroes Figures, and Heroes' Day}

The presence of a hero is an embryo for a role model, is instrumental to the country, and is willing to defend what is right. In the context of state and national life, a person is seen as a hero because of his services in fighting for the independence of the state and nation and for the sake of maintaining the independence and sovereignty of the state [8]. A hero is highly respected by the Indonesian and considered as an important person for the development of Indonesia, especially in the development of human character and moral values.

In general, a person can be categorized as a hero if the person concerned has a prominent character because of his courage and willingness to sacrifice in defending the truth for the benefit of his nation and country [3]. In-Law No. 20 of 2009 concerning Degrees, Merits, and Honors, in Chapter I, Article 1 (1) it is stated that a title is a state award given by the President to someone who has died or has died for their struggle, dedication, and service. extraordinary work for the nation and state. Meanwhile, in paragraph (4) it is explained that National Hero is a title given to an Indonesian citizen or someone who fought against colonialism in the area which is now the territory of 
International Journal of Social Science (IJSS)

Vol.1 Issue.4 December 2021, pp: 407-414

ISSN: 2798-3463 (Printed) | 2798-4079 (Online)

DOI: https://doi.org/10.53625/ijss.v1i4.718

the Unitary State of the Republic of Indonesia who died or died in defense of the nation and state, or who during his lifetime perform heroic acts or produce extraordinary achievements and works for the development and progress of the nation and state of the Republic of Indonesia.

The values of heroism, including fighting selflessly, responsibility, dedication, loyalty, sincerity, and example are values that are needed and need to be instilled continuously for the Indonesian nation today and in the future. Heroic values, such as fighting spirit and living up to the patriotic actions of the nation's heroes should be able to strengthen the sense of Indonesian nationality and statehood, not only when dealing with colonial occupation, but also after independence.

\section{National Heroes in the Indonesian Revolution The Hardline Groups}

The culmination of the struggle of the Indonesian people was on 17-08-1945 and at the same time served as the initial milestone for the eruption of the Indonesian revolution which lasted for approximately five years (19451950). After this nation proclaimed its independence, it does not mean the struggle is over [9]. Because in reality, the Dutch wanted to regain control and colonize the Indonesian people. The Indonesian people do not remain silent, various community alliances with their leaders struggle to maintain the independence and sovereignty of the country.

To defend Indonesia's independence, which had been proclaimed, the fighters took two paths, namely by war and fighting through diplomacy. During the period of the Indonesian revolution, the leaders actively fought in accordance with the paths/methods that had been agreed upon by their respective groups. These patterns of struggle are not only carried out by national figures, because in reality these patterns of struggle are also followed by local figures, including figures from the Bali area.

Historical actors who appeared to take part in the revolutionary period (1945-1950) were warriors whose personalities had been formed since the time of the movement. These figures in the struggle to defend their country's sovereignty are divided into two groups, namely hardliners and moderate groups. The first group, namely the hardliners, believed that the struggle to maintain their independence was carried out by means of violence. This means that this group strongly believes that the struggle by taking up arms to fight all obstacles is the best way to maintain the independence and sovereignty of their country.

The figures who appear to take part in their hardline group struggle with all their might only by taking up arms in defending the independence and sovereignty of their country. They believe that the best way to defend the independence and sovereignty of the country is to answer every obstacle, obstacle, and challenge by taking up arms. Methods like this in Bali were carried out by the "Ciungwanara" troops with figures such as I Gusti Ngurah Rai, I Gusti Wayan Debes, I Gusti Bagus Putu Wisnu, Sugianyar, and all Ciungwanara troops who died in armed contact in the "Puputan war" incident. Margarana" on 20 November 1946 in Uma Kaang Kelaci, Marga Village, Tabanan [10].

Although the leaders, important figures, and soldiers had died in the Puputan war, the fire of struggle continued because the fighting spirit they ignited was able to ignite the spirit of the community, namely the belief in the idea that once independence remains independent and must be independent until the ideal is achieved. That was why, even though I Gusti Ngurah Rai and other fighter figures died on the battlefield (Puputan Margarana), the struggle of this hard-line group was continued by young fighters who were still alive, such as I Made Widjakusuma (Pak Item), I.B. Tantra (Pak Poleng), Nyoman Mantik, Kompyang Sudjana, Ketut Widjana, Wayan Noor Rai, and I Gusti Ngurah Mataram [9].

\section{The Moderate Line Group}

In contrast to the strategy of the first group, which took the path of violence by taking up arms in solving the problems at hand. The second group or commonly known as the moderate line group in maintaining the independence and sovereignty of the state prefers diplomacy and through socio-political organizations. Those who chose this route were generally former Dutch colonial political prisoners, such as Gede Puger, Anom Gangga, Made Narsin, Ketut Mendra, dan Widjaka.

This group was supported by the older group, such as I Gusti Made Tamba, Gusti Putu Merta, dr. Nengah Ketut Nuridja, Drh. Made Geria, Made Kaler, and dr. Suwarno. These figures founded a political party, namely the Indonesian People's Party (PARRINDO) with the principle of fighting for an independent Indonesia and abolishing colonialism on Indonesian soil. On December 8, 1946, Parrindo formed a foundation engaged in education called Majelis Pendidikan Rakyat (MPR). Subsequently, the MPR established the Oemoem Advanced School (SLO) led by I Gusti Made Tamba. The SLO that tried by the MPR to strive to be a national education, just like Taman Siswa, which was dedicated to the nation's struggle to maintain independence, 17-08-1945. In subsequent developments, this SLO became the forerunner to the establishment of Perguruan Rakyat Saraswati Foundation in Denpasar, which still exists today. 
From the ranks of the moderate line groups, it turns out that local figures have emerged who have fought through diplomacy. This local figure fought diplomatically in the national arena together with other national figures, such as Mohammad Hatta, Moh. Natsir and others. The emergence of a local figure from Bali named Anak Agung Gede Agung was quite controversial, because after leaving his position as King of Gianyar he then entered the cabinet of the State of East Indonesia (NIT), and at its peak succeeded as Prime Minister of NIT. In his diplomatic struggle, this figure offered the idea of Indonesian federalism and received support from forums of federal states that emerged after NIT, such as Pasundan State, West Java, Central Java, East Java, Madura, South Sumatra, East Sumatra State, and Dayak.

Bijeenkomst voor Federal Overleg (BFO) or commonly known as the Forum of Federal States played an important role with the Republic of Indonesia in fighting for the recognition of sovereignty which later gave birth to a federal state according to the principles of Indonesian federalism [9], namely the United States of Indonesia (RIS). The establishment of the RIS state actually ended the struggle for the Indonesian revolution which was characterized by war and diplomacy.

The presence of the United Republic of Indonesia (RIS) caused a reaction among the people in the states. On the other hand, a movement arose that called for the establishment of a unitary state as a form of resistance to the federalists. In subsequent developments, one by one the states disbanded and declared to join the Proclamation State. On August 15, 1950, the last states, namely the State of East Indonesia (NIT) and the State of East Sumatra (NST) jointly handed over their mandate to the Prime Minister of RIS Moh. Hatta to merge his country and join the Republic of Indonesia (RI) into a unitary state which was later known as the Unitary State of the Republic of Indonesia (NKRI) based on the Proclamation 17-8-1945.

During the period of the Indonesian revolution, historical actors who led the struggle through war or who were active in negotiation and diplomacy emerged with their respective roles. They received an award from the Government of the Republic of Indonesia as national heroes for their services and loyalty to the Unitary State of the Republic of Indonesia. Their loyalty and sincerity in sacrificing their body and soul should be understood and imitated in relation to their struggle to defend the independence and sovereignty of the Indonesian country.

\section{National Hero and Meaning for the Young Generation}

In the Big Indonesian Dictionary, the word hero is defined as a valiant warrior, a person who stands out for his courage and sacrifice in defending the truth. Therefore, the word hero is actually related to the meaning of the qualities and actions of a person who is said to be a hero who is able to display a brave, chivalrous attitude in the face of danger, especially in war [1]. Strictly speaking, the hero can be described as having courage and determination, intelligence, and can cause a sense of emotion in the community. Every historical event is not something that has no meaning in life, but so many examples are passed down [11].

The illustration of a hero in the past is depicted as a character who wears a bullet sling on his body, is lifting a pointed bamboo or is wielding a sword/ dagger. The figure of the hero is depicted as appearing valiantly as a knight, even though in reality they lost and eventually died on the battlefield [3]. This understanding of heroes is a picture of heroes during the war in the past. Today war is no longer the reason someone chooses to be a hero as the life of the nation and state in this country becomes more stable. Based on this, the question arises, what requirements are needed today, so that someone can be appointed as a hero so that the meaning of hero will continue to develop according to the demands and dynamics of Indonesian society.

The true meaning of a hero is anyone who is willing and willing to help or do good to other people, the nation or the country without any sense of self-worth or expecting anything in return. We also have to know today's heroes, not just heroes who fought in colonial times. In fact, nowadays anyone can become a hero as long as they are willing and willing to help or do good to other people, the nation or the country without any sense of self-worth. On that basis, the hero is a role model, has contributed to the country, and is willing to defend what is right. A person can be said to be a hero if he has a character that stands out because of his courage and sacrifice in defending the truth as a valiant warrior. Because the role is so big, it is not an exaggeration if the services of warrior figures are always commemorated as Heroes' Day. Not only that, to commemorate his services, the names of the figures are engraved in history books, enshrined in street names, airport names, and in currency notes. However, many people do not know the history of the National Heroes contained in these banknotes. Indonesian people only use money as a means of buying and selling [12].

The starting point for the celebration of Heroes' Day when traced back, it is clear that the fierce battle that took place in Surabaya on November 10,1945, which claimed the lives of so many from the homeland fighters and also from the British army was a milestone. Therefore, every November 10, the Indonesian people commemorate Heroes' Day, especially to commemorate the struggle of the Arek Suroboyo bravely against the British army in an effort to maintain the independence and sovereignty of the country which was proclaimed 17-08-1945. They do not 
International Journal of Social Science (IJSS)

Vol.1 Issue.4 December 2021, pp: 407-414

ISSN: 2798-3463 (Printed) | 2798-4079 (Online)

DOI: https://doi.org/10.53625/ijss.v1i4.718

want to return to the colonial world, therefore the independence that has been achieved will be maintained even at the expense of body and soul.

The heroic events carried out by the Suroboyo group with the motto "life or death", presented charismatic kyai figures such as Kyai Haji Hasyim Asy'ary and Kyai Haji Wahab Hasbullah leading the resistance against British troops who were accompanied by Dutch interests. This event also featured a young man named Bung Tomo bravely standing in front of leading the battle against the British army. The determination of 10 November as Heroes' Day is based on a strong argument by looking at the extraordinary national commitment that has been shown by the heroes, especially the Suroboyo people to the Unitary State of the Republic of Indonesia.

The various examples shown and given by historical actors should be grateful for being used as social capital for the community, especially for the younger generation in continuing the ideals of the nation's struggle in building its future. One of the efforts that should be proud and at the same time appreciated that at that time the heroes were able to compete in the war against the British army, which was much more prepared in terms of weapons. But in reality, adequacy in weapons is not the only thing that determines success in winning the war. The spirit and determination to defend the independence and sovereignty of the country turned out to be far more powerful in fighting the invaders.

Observing the various events that occurred, the people in each region should understand the dynamics of the history of the region in order to gain a complete understanding of the process of the occurrence of the Indonesian nation and state in its further development. Thus, it will be continuously intertwined and connected historical lines in the past by understanding the present in the midst of the dynamics of Indonesian society.

The values inherited by heroes must be able to bring the younger generation in past abilities in the present with various adaptations and adoptions while maintaining the colors and characteristics of Indonesia in various aspects of religious, artistic, economic, social, cultural, science and technology life. 13]. The heroic values inherited by the younger generation must be able to make the past part of the present life with knowledge, ability, and awareness that the present is the past that lives in the present that continues to develop. The past is the present that continues to grow and be developed to build a future life. History is about human life and not just about a particular event [14]. This means that Indonesian history is about Indonesian people and not just fragments of certain events or periods in human life. Therefore, historical events are not something that stands alone and is separated from others because the society in which the historical event occurred becomes the heir, developer, guardian, and originator of new historical events in their present life.

Every historical event that is carried out by historical actors based on certain views is called a hero and basically, historical actors are those who have very high exemplary qualities [1]. The historical actor in his position as a leader shows an example in leadership that is able to cause many people to believe and support the noble ideals that are being fought for. The heroes have high intelligence in reading the problems of people's lives. They are able to formulate the problems faced by the community into ideals, gather strength in carrying out movements to achieve those goals.

In realizing their shared goals, they share a bitter taste, the spirit of sacrifice, togetherness, tolerance for differences, and high honesty. Without having such qualities, their struggle will be in vain and the shared ideals they dream of will never come true [15]. There are wise words that always ring in our ears and remind us that, "a great nation is a nation that respects and respects the services of its heroes". Heroes who are willing to sacrifice their lives to protect and defend the Indonesian state.

Honestly, most of our society did not participate in the struggle that cost thousands of lives while defending an independent Indonesia. However, this nation, especially the younger generation as the successors of the nation's struggle, should be able to give new meaning to heroism and fulfill independence according to the demands and developments of the times. Becoming a hero by imitating the fighting spirit of the fallen heroes by contributing to the development of the progress of the Indonesian nation in the future. The Indonesian nation needs so many heroes, heroes in all fields to realize a peaceful and progressive Indonesia.

The spirit of nationalism or love for the homeland that has been inherited by the heroes must not only be rote knowledge but must be internalized as part of the values of today's generation until it becomes real behavior in everyday life. Do not let the next generation of this nation know more about the figure or image of Ronaldo/Messi or Japanese cartoon characters on TV than the figures/images of the national heroes who have actually shed their blood for the sake of fighting for the upholding of the independence and sovereignty of their country.

Exemplary values must be attached to every young generation as a guide as well as capital to answer the challenges of global cultural flows. The inherited example can be used as social capital to become a citizen with sufficient individual ability in developing their own life, developing their potential which is built from the experiences of historical actors in various historical events in building their nation for the better. 
Currently, many young people are trapped in the negative development of the era of globalization so that they forget their responsibilities as the nation's next generation. As a result of the influence of liberalization in various aspects of human life, a setback is felt in interpreting the values of heroism. In today's case, national hero figures are needed by this nation in the context of answering various concrete problems of the nation. The Indonesian people are currently facing basic problems that need to be resolved while still referring to the values of heroism.

Embodiment The cultivation of the value of heroic struggle is applied to form a character of the nation's children who are intelligent and have the potential to become good and independent citizens [5]. Today, the real action is needed by the younger generation in appreciating the role models of heroes in accordance with the fields in which they serve. It is in this regard that it is necessary to study the values of heroism to be actualized in real life, for example in dealing with the problems of the quality of Indonesian human resources, poverty, problems in regions (farthest, outermost, frontier), damage to nature and the environment, democracy, and human rights, crises. The financial and economic crisis has an impact on the occurrence of political and socio-cultural crises with multidimensional dimensions, including how this nation is struggling to deal with the COVID-19 pandemic.

Therefore, the tradition of commemorating Heroes' Day if it is only ceremonial, it is time to abandon it because it is not in accordance with the nature of the commemoration of the historical event in question. Through the sacrifices that have been made by historical actors, it is evidence of the struggle that has been offered to their nation and not what their nation could give. This kind of exemplary attitude is very much needed and used as an example, especially for the younger generation in the context of developing the nation and state in the future.

\section{CONCLUSION}

Heroes in the past are described as appearing bravely as a knight wearing a bullet sling on his body, lifting a pointed bamboo or wielding a sword/dagger. This understanding of heroes is a picture of heroes during the war in the past. Today war is no longer the reason someone chooses to be a hero as the life of the nation and state in this country becomes more stable.

The true meaning of a hero is anyone who is willing and willing to help or do good to other people, the nation or the country without any sense of self-worth or expecting anything in return. The public and the younger generation must know that today's heroes are not just heroes who fought during the colonial era. Today anyone can become a hero as long as they are willing and willing to help or do good to others, the nation or the country without any sense of self-worth.

Learning from past historical experiences, when there was a great and heroic war in Surabaya, 10 November 1945, there were many valuable lessons to be learned. The heroic values that can be learned from these heroic events are actually the result of the accumulated experience of the nation and state in building the civilization of the Indonesian nation with character and virtuous character. Behind the commemoration of Heroes' Day, there is actually a message to the younger generation of the nation's successors to always fight to fill the struggle by instilling the values of nationalism and patriotism [11].

Heroic values such as fighting without self-restraint, persistent and unyielding, responsibility, loyalty, honesty, dedication, sincerity, and role model are values that are very much needed and need to be instilled in a sustainable manner for the Indonesian people, especially for the younger generation in building the nation and state. country in the future. The fighting spirit, patriotic actions of heroes as historical actors must be used as glue as well as national capital for present and future generations in building their nation in the universal era.

\section{REFERENCES}

[1] Caerulsyah. (2014). Persepsi Siswa Tentang Keteladanan Pahlawan Nasional untuk Meningkatkan Semangat Kebangsaan Melalui Pembelajaran Sejarah di SMA Negeri 4 Kota Tegal. https://www.google.com/search?q=PERSEPSI+SISWA+TENTANG+KE

[2] Agus, Efendi dan Zulfahmi. (2021). Pengaruh Globalisasi Terhadap Nilai Nasionalisme Generasi Muda. Euris Studia, Jurnal Kajian Hukum Vol. 2 No.1 http://jurnal.bundamediagrup.co.id/index.php/iuris/article/download/75/70

[3] Ardana, I Ketut. (2009). Pahlawan Nasional Paska-Proklamasi Kemerdekaan. Makalah disajikan dalam Seminar Nasional Sejarah, dengan tema "Pahlawan Nasional dan Kesadaran Bangsa". Denpasar, 16 Desember 2009.

[4] Brata, Ida Bagus. (2014). Bajra Sandhi: Monumen Perjuangan Rakyat Bali Sumbangan Terhadap Tegaknya Kedaulatan Negara Kesatuan Republik Indonesia. http://repository.unmas.ac.id/journal/detail/2533/

[5] Nireki, Lebda Tyas, Budi Purnomo, Anny Wahyuni. (2020). Manifestasi Perjuangan Jenderal Soedirman Pada Era Masa Kini di Indonesia. Literacy : Jurnal Ilmiah Sosial Volume 2, No. 1

https://literacy.fasanesia.com/index.php/jis/article/view/15 
International Journal of Social Science (IJSS)

Vol.1 Issue.4 December 2021, pp: 407-414

ISSN: 2798-3463 (Printed) | 2798-4079 (Online)

crossref DOI: $\underline{\text { https://doi.org/10.53625/ijss.v1i4.718 }}$

[6] Dinas Kebudayaan Provinsi Bali UPT. Monumen Perjuangan Rakyat Bali. (2013). Buku Panduan Monumen Perjuangan Rakyat Bali.

[7] Zed, Mestika. (2014). Metode Penelitian Kepustakaan. Jakarta: Yayasan Obor.

[8] Abdullah, Taufik; (2017). Pengajaran Sejarah yang Reflektif dan Inspiratif. Makalah disajikan dalam Seminar

Nasional dan Kongres Asosiasi Pendidik dan Peneliti Sejarah (APPS). Unimed, 13-15 Juli 2017.

[9] Pidada, Ida Bagus Astika. (2019). Cara-Cara NICA Mempengaruhi Rakyat Supaya Tidak Bersimpati Kepada Para Pejuang pada Masa Revolusi Fisik di Bali 1945-1950. Kulturistik, Vol.3 No.2 https://ejournal.warmadewa.ac.id/index.php/kulturistik

[10] I Gusti Ayu Kristianingrat1, I Gusti Ayu dan Kertih, I Wayan (2019). Menggali Nilai-Nilai Kepahlawanan I Gusti Ngurah Rai sebagai Sumber Pendidikan Karakter dalam Pembelajaran IPS. Jurnal Pendidikan IPS, Vol. 3 No. 2, https://ejournal-pasca.undiksha.ac.id/index.php/PIPS/article/download/3336/1671

[11] Rasyid, Moh. (2014). Penanaman Nilai Kepahlawanan dalam Pendidikan dengan Memanfaatkan Data Sejarah.

Sekolah Tinggi Agama Islam Negeri (STAIN) Kudus https://media.neliti.com/media/publications/70288-ID penanaman-nilai-kepahlawanan-dalam-pendi.

[12] Noor Seto, Muhammad Hadi, Tri Listyorini, Arief Susanto. (2015). Pengenalan Pahlawan Indonesia Berbasis Augmented Reality dengan Marker Uang Indonesia. Pros iding SNATIF Ke -2 https://jurnal.umk.ac.id/index.php/SNA/article/view/302

[13] Mantra, I.B.G.Wirawibawa. (2009). Nilai Kepahlawanan dan Pembangunan untuk Generasi Muda. Makalah disajikan dalam Seminar Nasional Sejarah, dengan tema "Pahlawan Nasional dan Kesadaran Bangsa". Denpasar, 16

Desember 2009.

[14] Hasan, S. Hamid. (2017). Pendidikan Sejarah untuk Kehidupan Berbangsa dan Masa Depan Bangsa. Makalah disajikan dalam Seminar Nasional dan Kongres Asosiasi Pendidik dan Peneliti Sejarah (APPS). Unimed, 13-15 Juli 2017.

[15] Ricklefs, M.C. 1994. Sejarah Indonesia Modern. Yogyakarta: Gajah Mada University Press. 
